\title{
Ethnozoological study of traditional medicinal appreciation of animals and their products among the indigenous people of Metema Woreda, North-Western Ethiopia
}

\author{
Fasil Adugna Kendie*, Sileshi Andualem Mekuriaw and Melkamu Andargie Dagnew
}

\begin{abstract}
Background: Using animals for different purposes goes back to the dawn of mankind. Animals served as a source of food, medicine, and clothing for humans and provided other services. This study was designed to undertake a cross-sectional ethnozoological field survey among the residents of Metema Woreda from November 2015 to May 2016.

Methods: Data were collected through studied questionnaires, interviews, and focus group discussions with 36 purposively selected respondents.

Results: Ethnozoological data were collected of the local name of the animals, part of the animal used, mode of preparation and administration, and of additional information deemed useful. A total of 51 animal species were identified to treat around 36 different ailments. Of the animals used therapeutically, 27 species were mammals, 9 were birds, 7 arthropods, 6 reptiles, and 1 species each represented fish and annelids. Furthermore, the honey of the bee Apis mellifera was used to relieve many ailments and scored the highest fidelity value $(n=35.97 \%)$. The snake (Naja naja) and the teeth of crocodiles (Crocodylus spp.) had the lowest fidelity value $(n=2.56 \%)$.

Conclusion: The results show that there is a wealth of ethnozoological knowledge to be documented which could be of use in developing new drugs. Hence, it is hoped that the information contained in this paper will be useful in future ethnozoological, ethnopharmacological, and conservation-related research of the region.
\end{abstract}

Keywords: Traditional medicine, Indigenous knowledge, Ethnozoology, Zootherapy

\section{Background}

Using animals for different purposes goes back to the dawn of mankind. Animals served as a source of food, medicine, and clothing for humans and provided other services [1]. The traditional medicinal knowledge of indigenous people across the globe has played an important role in identifying living organisms which are endowed with medicinal values important for treating human and livestock health problems. Since ancient times, animals and their products have been used in the preparation of traditional remedies in various cultures [2]. Human societies have accumulated a vast store of knowledge about animals through the centuries,

\footnotetext{
* Correspondence: fasiladugna@gmail.com

Department of Biology, College of Science, Bahir Dar University, P.O. Box 79, Bahir Dar, Ethiopia
}

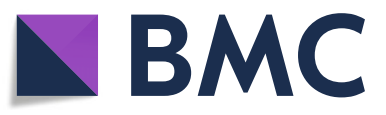

(c) The Author(s). 2018 Open Access This article is distributed under the terms of the Creative Commons Attribution 4.0 International License (http://creativecommons.org/licenses/by/4.0/), which permits unrestricted use, distribution, and

reproduction in any medium, provided you give appropriate credit to the original author(s) and the source, provide a link to the Creative Commons license, and indicate if changes were made. The Creative Commons Public Domain Dedication waiver (http://creativecommons.org/publicdomain/zero/1.0/) applies to the data made available in this article, unless otherwise stated.

which is closely integrated with many other cultural aspects, and this zoological knowledge is an important part of our human cultural heritage [3].

The cure for human ailments using therapeutics from animals is known as zootherapy [4]. It plays a significant role in the healing practices, magic rituals, and religious societies all over the world $[5,6]$. In the modern era, zootherapy constitutes a major alternative among many other known therapeutic practices in the world. Wild as well as domestic animals and their by-products such as hooves, skins, bones, feathers, and tusks serve as important ingredients in the preparation of curative, protective, and preventive medicines $[5,7,8]$.

Traditional medicines have been important in connection with drugs like digitoxin, reserpine, tubocurarine, and 
ephedrine [9]. Of the 252 essential chemicals that have been selected by the World Health Organization, $8.7 \%$ come from animals [10].

Loss of traditional knowledge of indigenous communities had impact the development of modern medicine. It is important to document the traditional knowledge of human communities, since the majority of such communities are losing their socioeconomic and cultural characteristics [10]. Animals and the products derived from their body organs constitute part of the inventory of medicinal substances which are used widely by the people since time immemorial, and such practices still exist in traditional medicines [10]. Traditional healing methods involving hundreds of insect and other invertebrate species are reviewed by Meyer-Rochow [11]. In South Africa, animals and plants are commonly used as traditional medicines for both the healing of ailments and for symbolic purposes such as improving relationships and attaining good fortune [12].

In Traditional Chinese Medicine, more than 1500 animal species had been recorded to be some medicinal use [13]. In Brazil, Alves and Rosa reported the medicinal use of 283 animal species for the treatment of various ailments [14-17].

In Ethiopia, 70\% of human and 90\% of livestock population depend on traditional medicine. Although Ethiopians are known for their widespread use of traditional medicines with various levels of sophistication within the indigenous medical lore, the vast knowledge of the traditional uses of animal species of therapeutic value is not well documented for the various regions of the country. Moreover, since most of the knowledge is conveyed along generations through word of mouth, the traditional knowledge as well as the products used by these people is under threat [18].

In Metema Woreda, there were a number of studies about ethnobotany and traditional medicine, diversity, and floristic compositions of plants. However, despite the great diversity of ethnic groups and cultures in this area, ethnozoological studies of traditional medicinal animals have not yet been sufficiently addressed. Metema Woreda is characterized by the presence of a mosaic of ethnic groups with deep rooted culture of using traditional medicinal plants and animals. Hence, this study is aimed to explore ethnozoology and preparations of animals and its products as traditional medicine used to cure different human and animal ailments.

\section{Methods}

\section{Study area description}

The study was conducted in Metema Woreda in the Amhara National Regional State. The Woreda is about $333 \mathrm{~km}$ to the North West of Bahir Dar, the Capital City of Amhara Regional State. Metema is one of the Woredas in the Semien Gondar Zone, bordered by Qwara in the south, Sudan in the west, Mirab Armachiho in the north,
Tach Armachiho in the northeast, Chilga in the east, and Takusa in the southeast. The Woreda constitutes a total of 20 Peasant Kebele administrations, of which 18 are ruralbased peasant administration areas $[19,20]$. The Woreda is the home of many ethnic groups including Agaw, Tigrie, Oromo, Gumuz, and Amhara migrated from the different angles of the country for different reasons displaying a diversity of cultures and indigenous belief.

\section{Selection of study sites}

A preliminary study was conducted in November 2015 to select specific study sites in the Woreda and test data collection tools. The study was conducted in six kebeles of Metema Woreda (Birshign; Kokit; Mender 6, 7, and 8; Metema Yohannis; Aftit; and Meka) from November 2015 to May 2016. These kebeles were purposively selected based on the availability of many traditional healers, presence of different ethnic groups, and accessibility of the area.

\section{Sampling and data collection}

The ethnozoological data (local name of animals, mode of preparation and administration, and part of the animal used) were collected through questionnaires, interviews, and focus group discussion with selected residents of Metema Woreda. Purposively, 36 key informants were selected, and questionnaires, interviews, and focus group discussion were made within these informants [21]. These informants were local herbalists, traditional healers, farming experts, midwives, and spiritual intellectuals. The selections of key informants were based on their experience and recognition as knowledgeable members concerning traditional zootherapeutics (the so called expert by the local people) [22]. Different types of ethnozoological data were collected from each type of key informants.

\section{Group discussion}

Brief group discussions were made at each site prior to the distribution of detailed questionnaires on the importance of animals in traditional medicine and related issues with the selected informants of the study site. During the discussions, an attempt was made to encourage the healers in such a way that their cooperation would be of benefit to the country and at same time an informed consent was obtained before data collection.

\section{Semi-structured interviews}

A semi-structured checklist and interview questions were prepared in advance. The interviews were based on this checklist, and some issues were raised promptly depending on the responses of an informant. The interview was held in Amharic, the language of the people by the researchers. The place and time for the discussion was set based on the interest of the informants. 
Table 1 Socio-demographic characteristics of the respondents

\begin{tabular}{lll}
\hline Basic information & Number of respondents & Percentage (\%) \\
\hline Sex & 34 & 94.4 \\
Male & 2 & 5.6 \\
Female & & \\
Age & 6 & 16.7 \\
$35-44$ years & 20 & 55.5 \\
$45-60$ years & 10 & 27.8 \\
$>60$ years & & \\
Educational level & 15 & 41.7 \\
Illiterate & 21 & 58.3 \\
Literate & & \\
Marital status & 34 & 94.4 \\
Married & 1 & 2.8 \\
Single & 1 & 2.8 \\
Divorced & & \\
\hline
\end{tabular}

\section{Informant consensus}

During the course of the study, each informant was visited three times in order to confirm the reliability of the ethnozoological information. Consequently, the responses of an informant that were not in harmony with each other were rejected since they were considered as unreliable information.

\section{Animal specimen collections and identifications}

The local names and associated attributes of medicinal animals were recorded for each of the species. The specimens with its common name, photograph, dead skin, hair, fur, and some products were collected and taken to Bahir Dar University (BDU) for species identification. Identification of the medicinal animals was done in BDU, using Internet and animal key by comparison with collected plates and illustrations.

Table 2 Information that was acquired by close-ended questionnaire

\begin{tabular}{|c|c|c|c|c|}
\hline No. & Questions & Choices & No. of respondents & Percentage (\%) \\
\hline \multirow[t]{5}{*}{1} & \multirow[t]{5}{*}{ Where did you learn traditional medicinal knowledge? } & A) Family & 16 & 44.4 \\
\hline & & B) Books & 4 & 11.1 \\
\hline & & C) Surrounding society & 12 & 33.3 \\
\hline & & D)Experience & 4 & 11.1 \\
\hline & & Total & 36 & \\
\hline \multirow[t]{4}{*}{2} & \multirow[t]{4}{*}{ How many times people use traditional medicines? } & A) Sometimes & 15 & 41.7 \\
\hline & & B) Always & 13 & 36.1 \\
\hline & & C) Situational & 8 & 22.2 \\
\hline & & Total & 36 & \\
\hline \multirow[t]{4}{*}{3} & \multirow[t]{4}{*}{ What was the reason that forces the people to use traditional medicines? } & A) Economy & 7 & 19.4 \\
\hline & & $\begin{array}{l}\text { B) Lack of modern } \\
\text { medicine }\end{array}$ & 10 & 27.8 \\
\hline & & C) Effectiveness & 19 & 52.8 \\
\hline & & Total & 36 & \\
\hline \multirow[t]{5}{*}{4} & \multirow[t]{5}{*}{ Which categories of people use traditional medicines in large quantity? } & A) Ethnic group & 5 & 13.9 \\
\hline & & B) Nations & 1 & 2.8 \\
\hline & & C) Religion & 5 & 13.9 \\
\hline & & D) All & 25 & 69.4 \\
\hline & & Total & 36 & \\
\hline \multirow[t]{4}{*}{5} & \multirow[t]{4}{*}{ What looks like the outlooks of people about use of traditional medicines? } & A) Good & 15 & 41.7 \\
\hline & & B) Bad & 1 & 2.8 \\
\hline & & C) Intermediate & 20 & 55.5 \\
\hline & & Total & 36 & \\
\hline \multirow[t]{4}{*}{6} & \multirow{4}{*}{$\begin{array}{l}\text { Are there any conservation and documentation mechanisms of traditional } \\
\text { medicinal animals? }\end{array}$} & A) Yes & 3 & 8.3 \\
\hline & & B) $\mathrm{No}$ & 31 & 86.1 \\
\hline & & C) Some & 2 & 5.5 \\
\hline & & Total & 36 & \\
\hline
\end{tabular}


Table 3 Animal groups and number of species used for traditional medicine in the study area

\begin{tabular}{llll}
\hline No. & Animal groups & Number of species & Percentage (\%) \\
\hline 1 & Mammals & 27 & 52.9 \\
2 & Birds & 9 & 17.6 \\
3 & Reptiles & 6 & 11.8 \\
4 & Fish & 1 & 2 \\
5 & Arthropods & 7 & 13.7 \\
6 & Annelid & 1 & 2 \\
\hline
\end{tabular}

\section{Data analysis}

The data obtained were summarized and analyzed using descriptive statistical methods. In the ethnozoological data that were obtained from the interviews on reported medicinal animals and associated knowledge, fidelity level (FL) was calculated as the percentage of respondents claiming the use of a certain animal species for the same ailments, for the most frequently reported diseases or ailments as

$$
\mathrm{FL}(\%)=\mathrm{Np}^{*} 100 / N
$$

where $N p$ is the number of respondents that claim a use of a species to treat a particular disease and $N$ is the number of respondents that use the animals as a medicine to treat any given disease [23]. The range of fidelity level (FL) is from 1 to $100 \%$; high values indicate that this particular animal species is used by large number of people, while a low value shows that respondents disagree on the usefulness of a species in treating ailments.

\section{Results}

This study revealed the traditional medicinal knowledge of treating various kinds of ailments using different animals and their parts/products by local inhabitants of different kebeles of Metema Woreda (North-Western Ethiopia). Many people were found to lack formal

Table 4 Animal parts or products used to traditional medicine in the study area

\begin{tabular}{|c|c|c|c|}
\hline No. & $\begin{array}{l}\text { Medicinal parts/products } \\
\text { of animals }\end{array}$ & $\begin{array}{l}\text { No. of parts/ } \\
\text { products used }\end{array}$ & Percentage (\%) \\
\hline 1 & Meat/fat & 23 & 23.5 \\
\hline 2 & $\begin{array}{l}\text { Visceral organ (liver, spleen, Bile, } \\
\text { stomach/intestine) }\end{array}$ & 21 & 21.4 \\
\hline 3 & $\begin{array}{l}\text { Products (honey, venom, milk, } \\
\text { butter) }\end{array}$ & 13 & 13.3 \\
\hline 4 & Bone/teeth & 12 & 12.2 \\
\hline 5 & $\begin{array}{l}\text { External Body part (head, tail, leg, } \\
\text { skin, horn, spine/thorn) }\end{array}$ & 12 & 12.2 \\
\hline 6 & Excreta (stool and urine) & 6 & 6.1 \\
\hline 7 & Whole body & 6 & 6.1 \\
\hline 8 & Blood & 5 & 5.1 \\
\hline
\end{tabular}

Table 5 Mode of application/administrations of traditional medicines

\begin{tabular}{lllll}
\hline $\begin{array}{l}\text { No. } \\
\text { Mode of } \\
\text { application }\end{array}$ & $\begin{array}{l}\text { No. of } \\
\text { application }\end{array}$ & $\begin{array}{l}\text { Percentage } \\
(\%)\end{array}$ & $\begin{array}{l}\text { Mode of } \\
\text { entry }\end{array}$ \\
\hline 1 & Eating & 30 & 28.0 & Oral \\
2 & Drinking & 27 & 25.2 & Oral \\
3 & Tying & 18 & 16.8 & Not enter \\
4 & Anointing & 14 & 13.1 & Dermal \\
5 & Banding & 6 & 5.6 & Dermal \\
6 & Massaging & 6 & 5.6 & Dermal \\
7 & Fumigation & 3 & 2.8 & Nasal \\
8 & Heating & 3 & 2.8 & Dermal \\
\hline
\end{tabular}

schooling education, but they have knowledge about the use of local animal resources for traditional medicines.

Socio-demographic characteristics of the respondents such as sex, age, educational level, and marital status were collected and presented (Table 1).

Information regarding the way to acquire traditional medicinal knowledge, duration of time to use traditional medicine, the reason that forces the people to use traditional medicines, categories of people that use traditional medicine, the outlooks of people about the use of traditional medicine, conservation, and documentation mechanisms of traditional medicinal animals were gathered from all respondents (Table 2).

Fifty-one animal species (Table 5) were found to be used for the treatment of over 36 kinds of ailments. There were 27 species belonging to mammals, 9 to birds, 7 arthropods, 6 reptiles, and 1 each among the fish and annelid (Table 3 ).

The animals and their parts/products were found to be used for the treatment of around 36 different kinds of ailments including rheumatism, malaria, wart, stomachache, toothache, herpes, headache, rabies, tuberculosis, anemia, trachoma, gastritis, asthma, paralysis, and cough. The animals were used as whole or their products like milk, blood, organ, meat, teeth, and honey for the treatment of various ailments (Table 8 ).

According to the data (Table 4), meat/fat was the most widely used medicinal parts/products of animals in traditional medicine, followed by visceral organs, products and bone/teeth, and external body parts with similar percentages. On the other hand, an animal's whole body and excreta, and blood were found to be the least used medicinal parts/products of animals.

In the study area, different parts or products of animals were used to treat different types of ailments. The highest number of cow parts or products $8(3.8 \%)$ used to treat $8(4.5 \%)$ ailments. The second rank was occupied by common warthog (Phacochoerus africanus), porcupine (Hystrix spp.), spotted hyena (Crocuta crocuta), and elephant (Elephas maximus) with similar number of parts/products $5(2.5 \%)$ and used to treat 8 (4.5\%), 13 (7. 


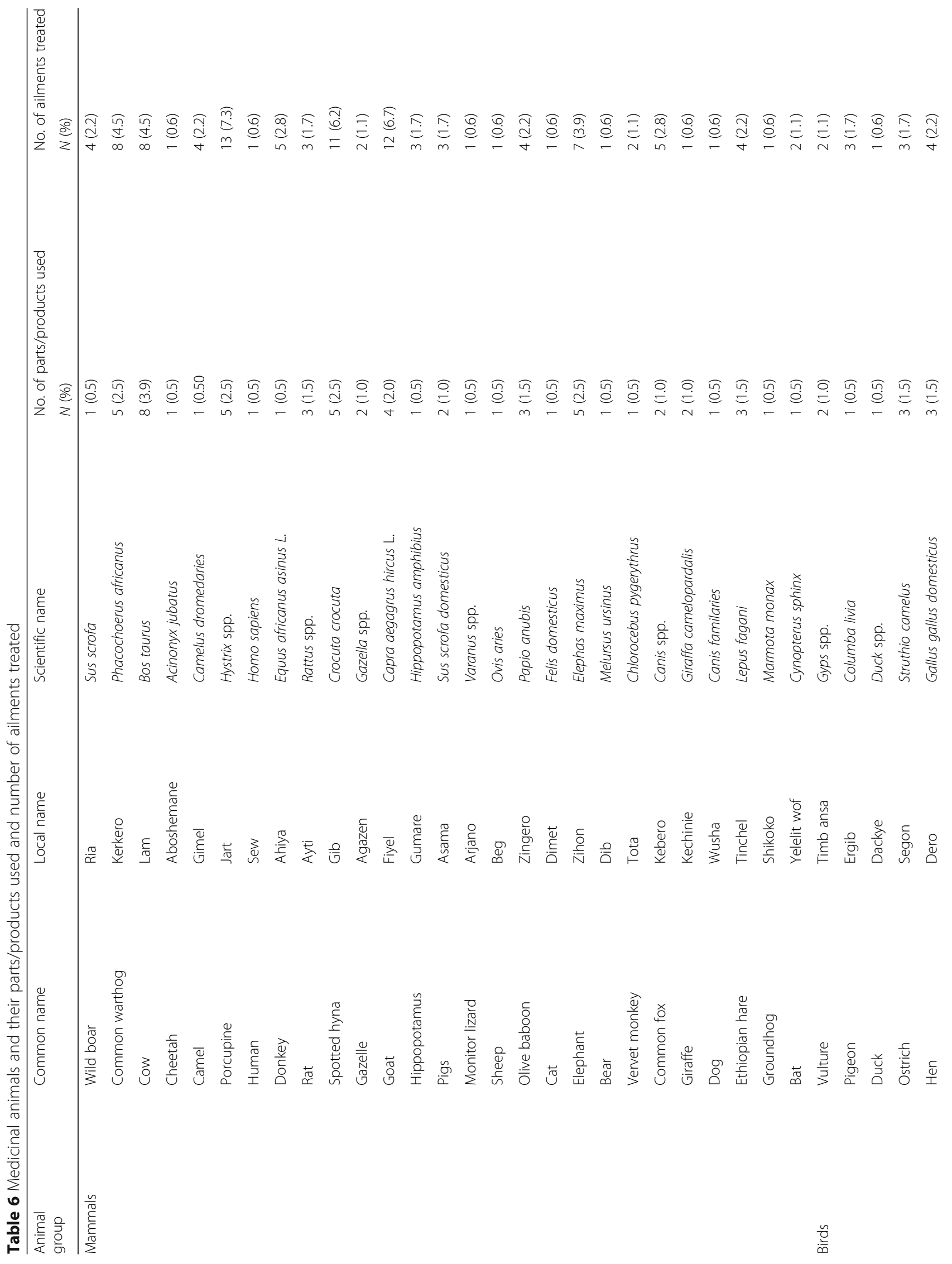




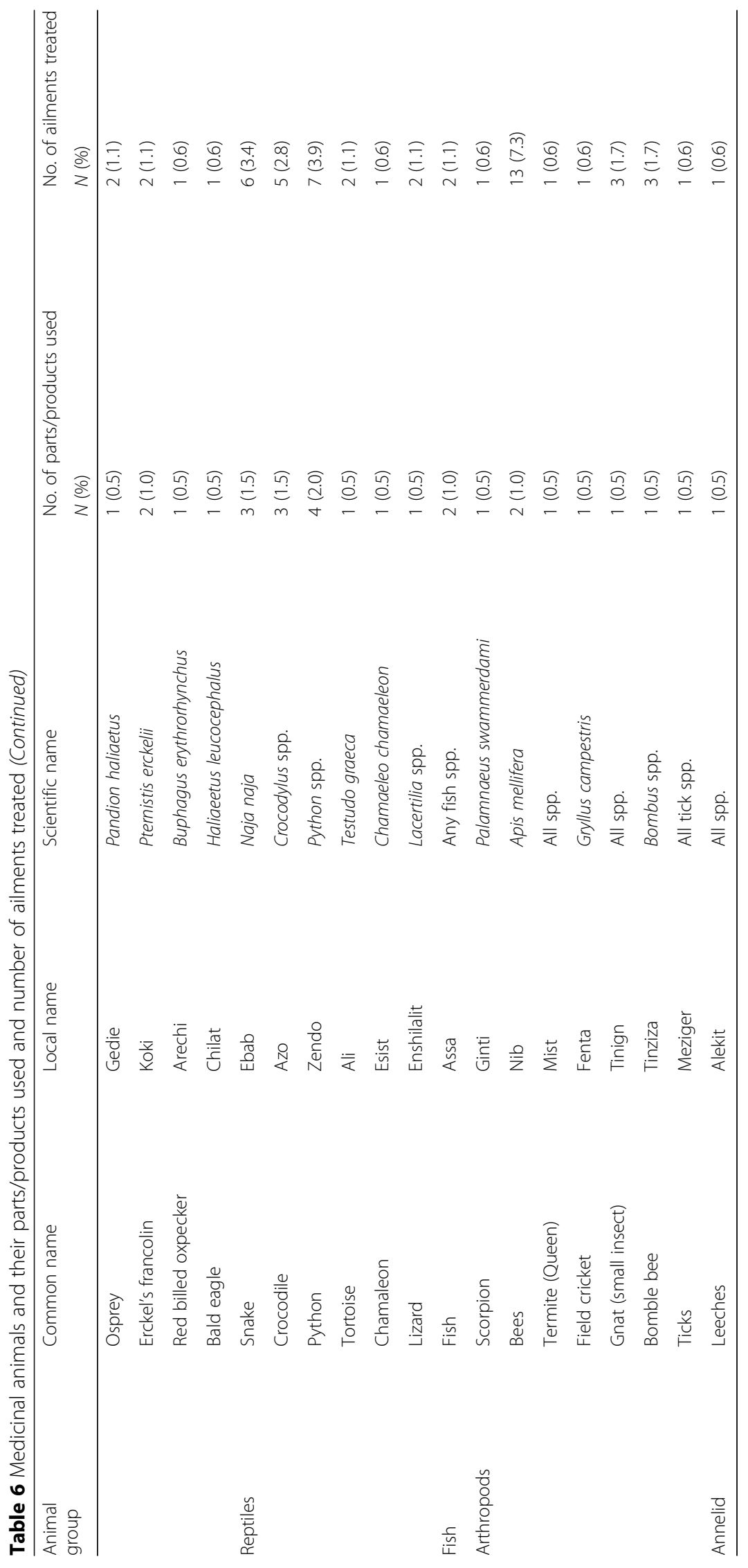


5\%), $11(6.2 \%)$, and $7(3.9 \%)$ ailments, respectively (Table 5).

Preparations varied according to ailment and involved cooking, burning, crushing/grinding, wrapping, powdering, and drying or the use of fresh animal parts/products (Table 6).

The traditional medicines were administrated via different modes. Eating, followed by drinking, tying, anointing, banding and massaging and, fumigation and heating were the major modes of application (Table 7). Solids and liquids were administered orally, whereas banding, heating, anointing, and massaging materials were applied to the skin. Medicinal fumes were allowed to enter the body via the nose, while some parts of animals like bones, skin, and teeth were believed to serve a healing purpose by tying them on the neck or other parts of the body. Most of the remedies did not involve the addition of substances like sugar, water, butter, honey, teff and millet flour, salt, spice, milk, egg, and coffee, but there were cases in which such additives were used.

Fidelity levels (FL) demonstrate the percentage of respondents claiming the use of a certain animal or its product for the same ailments. The honey of bee species (Apis mellifera) used to relieve wart, asthma, diarrhea, throat pain, stomachache, cough, and tuberculosis had the highest FL $(n=35,97 \%)$ followed by meat of wild boar (Sus scrofa) to treat rheumatism, syphilis, stomachache, and malaria $(n=32,89 \%)$, milk of goat (Capra aegagrus hircus) to treat eye disease, gastritis, headache, measles, tuberculosis, vomiting, and rheumatism ( $n=27$, $75 \%$ ), teeth of the common warthog (Phacochoerus africanus) to treat toothache, wart, and rheumatism ( $n=26$, $72 \%$ ), meat of the porcupine (Hystrix spp.) to treat swelling, tuberculosis, headache, AIDS, asthma, rheumatism, and gastritis $(n=24,67 \%)$, and urine of Gazelle (Gazella spp.) to treat urination problems $(n=23,64 \%)$. On the other hand, biles of common fox (Canis spp.) to cure eye problem and toothache $(n=2,5.6 \%)$, the upper skin of the snake (Naja naja) to cure headache $(n=2,5.6 \%)$, and the

Table 7 Methods of preparation of traditional medicinal in the

\begin{tabular}{llll}
\multicolumn{2}{l}{ study area } \\
\hline No. & Types of preparation & No. of preparation & Percentage (\%) \\
\hline 1 & Fresh & 40 & 36.4 \\
2 & Cooking & 26 & 23.6 \\
3 & Burning & 15 & 13.6 \\
4 & Crushing/grinding & 8 & 7.3 \\
5 & Wrapping & 8 & 7.3 \\
6 & Powdering & 7 & 6.4 \\
7 & Drying & 6 & 5.4 \\
\hline
\end{tabular}

teeth of crocodile (Crocodylus spp.) to cure epilepsy $(n=2$, $5.6 \%$ ) have the lowest fidelity level value (Table 8 ).

\section{Discussion}

In Ethiopia, $70 \%$ of human and $90 \%$ of livestock population depend on traditional medicine [18]. In this study, 51 animal species and their products were collected and identified that were believed to be a cure/prevention of over 36 kinds of ailments. Other studies reported in Ethiopia showed that approximately 23 animals and/or their parts were identified to be used in traditional medicines in Degu tribes in Tigray region [22]. Sixteen species of medicinal animals were collected and identified for treating 18 different human ailments in the Kafta-Humera District, Northern Ethiopia [24]. The study conducted by Borah and Prasad recorded a total of 44 different species of animals which are used for the treatments of 40 different ailments [21]. In South Africa, Whiting et al. identified 147 medicinal vertebrate species representing 60 mammal species, 33 reptile species, 53 bird species and 1 amphibian species [12]. Oliveira et al. also described 23 animal species that used as traditional medicines [25]. Of a total 36 vertebrate species used in the treatment of ailments and disease, mammals comprised 50\%; they were birds, fishes, reptile, and amphibians [26].

The inhabitants of the study area were found to use different parts/products of animals for the treatment of different kinds of ailments. Animals and the products derived from their body organs constitute part of the inventory of medicinal substances [10]. Meyer-Rochow also reported different organs of invertebrate animals used as traditional medicines [11].

In this study, parts/products of medicinal animals were grouped under meat/fat, blood, visceral organ, whole body, excreta, bone/teeth, and product categories and these categories were similar to ones reported by Haileselasie [22]. Other researches also stated that wild and domestic animals and their by-products such as hooves, skins, bones, feathers, and tusks are important ingredients in the preparation of curative, protective, and preventive medicine [7-9].

Preparations varied according to ailment and involved cooking, burning, crushing/grinding, wrapping, powdering, and drying [11]. In this study, egg is considered as one of the products of animals. The egg of ostrich (Struthio camelu) was mentioned as a traditional medicine in Table 8 . It is used to treat muscle strain, broken bone, and paralysis. Gidey Yirga et al. showed medicinal animals have various methods of preparation for different types of ailments like crushing, powdering, squeezing, direct use, and cooking [27]. Haileselasie reported that animals are used as whole or body parts or byproducts like milk, blood, organ, flesh, antler, and feathers for the treatments of different kinds of human ailments including cough, asthma, tuberculosis, paralysis, earache, herpes, weakness, and muscular pain [22]. 
Table 8 Medicinal animals, parts/products used, and their fidelity level

\begin{tabular}{|c|c|c|c|c|c|c|c|}
\hline $\begin{array}{l}\text { Animal } \\
\text { group }\end{array}$ & $\begin{array}{l}\text { Common } \\
\text { name }\end{array}$ & Scientific name & $\begin{array}{l}\text { Parts/product } \\
\text { used }\end{array}$ & $\begin{array}{l}\text { Ailments } \\
\text { treated }\end{array}$ & $\begin{array}{l}\text { No. of } \\
\text { respondents } \\
\text { claimed }(n)\end{array}$ & $\begin{array}{l}\text { Fidelity } \\
\text { level (FL) }\end{array}$ & $\begin{array}{l}\text { Mode of } \\
\text { applications }\end{array}$ \\
\hline \multirow[t]{32}{*}{ Mammals } & Wild boar & Sus scrofa & Meat & $\begin{array}{l}\text { Rheumatism, syphilis, } \\
\text { stomachache, and } \\
\text { malaria }\end{array}$ & 32 & 89 & Eating \\
\hline & Common warthog & Phacochoerus africanus & Teeth & $\begin{array}{l}\text { Swelling, toothache, } \\
\text { wart and rheumatism }\end{array}$ & 26 & 72 & Heating \\
\hline & & & Blood & $\begin{array}{l}\text { Malaria, asthma, and } \\
\text { rheumatism }\end{array}$ & 12 & 33 & Drinking \\
\hline & & & Skin & Herpes & 4 & 11 & Anointing \\
\hline & & & Bile & AIDS & 8 & 22 & Drinking \\
\hline & & & Horn & Swelling & 4 & 11 & Heating \\
\hline & Cow & Bos taurus & Butter & Malaria and paralysis & 8 & 22 & Eating \\
\hline & & & Milk & Rabies and TB & 18 & 50 & Drinking \\
\hline & & & Urine & Malaria & 4 & 11 & Drinking \\
\hline & & & Spleen & $\begin{array}{l}\text { Anemia, malaria and } \\
\text { trachoma }\end{array}$ & 13 & 36 & Eating \\
\hline & & & Omasum & Gastritis & 4 & 11 & Eating \\
\hline & & & Liver & Anemia & 9 & 25 & Eating \\
\hline & & & Blood & Wart & 10 & 28 & Drinking \\
\hline & Cheetah & Acinonyx jubatus & Skin & Hemorrhage & 3 & 8 & Tying \\
\hline & Camel & Camelus dromedarius & Milk & $\begin{array}{l}\text { Headache, rheumatism, } \\
\text { malaria and diarrhea }\end{array}$ & 20 & 56 & Drinking \\
\hline & Porcupine & Hystrix spp. & Meat & $\begin{array}{l}\text { Swelling, TV, headache, } \\
\text { AIDS, asthma, rheumatism, } \\
\text { gastritis, and hypertension }\end{array}$ & 24 & 67 & Eating \\
\hline & & & Bile & $\begin{array}{l}\text { Asthma/diabetes, } \\
\text { stomach scramble }\end{array}$ & 11 & 31 & Drinking \\
\hline & & & $\begin{array}{l}\text { Stomach/ } \\
\text { intestine }\end{array}$ & Diarrhea and diabetes & 7 & 19 & Eating \\
\hline & & & Thorn/spine & Wound and broken leg & 14 & 39 & Tying \\
\hline & & & Liver & Diabetes disease & 3 & 8 & Eating \\
\hline & Human & Homo sapiens & Stool & Wart & 3 & 8 & Anointing \\
\hline & Donkey & Equus africanus asinus $L$. & Milk & $\begin{array}{l}\text { Measles, cough, } \\
\text { trachoma/rabies, } \\
\text { and internal problem }\end{array}$ & 22 & 61 & Drinking \\
\hline & Rat & Rattus spp. & Meat & Intestinal disease & 5 & 14 & Eating \\
\hline & & & Foot & Nightmare & 4 & 11 & Tying \\
\hline & & & Blood & Wart & 6 & 17 & Anointing \\
\hline & Spotted hyna & Crocuta crocuta & Bone & Epilepsy and bad spirit & 12 & 33 & Tying \\
\hline & & & Skin & $\begin{array}{l}\text { Protection from evil } \\
\text { eye and during labor }\end{array}$ & 9 & 25 & Tying \\
\hline & & & Bile & $\begin{array}{l}\text { Erythroblastosis } \\
\text { and nightmare }\end{array}$ & 8 & 22 & Tying \\
\hline & & & Liver & Infection of skin & 5 & 14 & Banding \\
\hline & & & Skin & $\begin{array}{l}\text { For communicable } \\
\text { diseases and bad spirit }\end{array}$ & 11 & 31 & Tying \\
\hline & & & Meat & $\begin{array}{l}\text { For swollen sex organ, } \\
\text { epilepsy and anemia }\end{array}$ & 5 & 14 & Eating \\
\hline & Gazelle & Gazella spp. & Urine & For urination problem & 23 & 64 & Drinking \\
\hline
\end{tabular}


Table 8 Medicinal animals, parts/products used, and their fidelity level (Continued)

\begin{tabular}{|c|c|c|c|c|c|c|c|}
\hline $\begin{array}{l}\text { Animal } \\
\text { group }\end{array}$ & $\begin{array}{l}\text { Common } \\
\text { name }\end{array}$ & Scientific name & $\begin{array}{l}\text { Parts/product } \\
\text { used }\end{array}$ & $\begin{array}{l}\text { Ailments } \\
\text { treated }\end{array}$ & $\begin{array}{l}\text { No. of } \\
\text { respondents } \\
\text { claimed }(n)\end{array}$ & $\begin{array}{l}\text { Fidelity } \\
\text { level (FL) }\end{array}$ & $\begin{array}{l}\text { Mode of } \\
\text { applications }\end{array}$ \\
\hline & & & Bile & Syphilis & & 0 & Drinking \\
\hline & \multirow[t]{4}{*}{ Goat } & \multirow[t]{4}{*}{ Capra aegagrus hircus L. } & Milk & $\begin{array}{l}\text { Eye disease, gastritis, } \\
\text { wound, headache, measles, } \\
\text { TB, eye disorder, vomiting, } \\
\text { snake poison, and } \\
\text { rheumatism }\end{array}$ & 27 & 75 & Drinking \\
\hline & & & Fat & Wound and Toothache & 16 & 44 & Banding \\
\hline & & & Liver & Trachoma & 7 & 19 & Massaging \\
\hline & & & Butter & Headache and ear infection & 8 & 22 & Massaging \\
\hline & Hippopotamus & $\begin{array}{l}\text { Hippopotamus } \\
\text { amphibius }\end{array}$ & Bone & $\begin{array}{l}\text { Breast swelling, sunburn, and } \\
\text { body fracture }\end{array}$ & 6 & 17 & $\begin{array}{l}\text { Banding, } \\
\text { drinking }\end{array}$ \\
\hline & \multirow[t]{2}{*}{ Pig } & \multirow[t]{2}{*}{ Sus scrofa } & Meat & Rheumatism and headache & 4 & 11 & Eating \\
\hline & & & Blood & Skin infection & 4 & 11 & Anointing \\
\hline & Monitor lizard & Varanus spp. & Skin & $\begin{array}{l}\text { Infant communicable } \\
\text { disease }\end{array}$ & 6 & 17 & Tying \\
\hline & Sheep & Ovis aries & Milk & Malaria & 4 & 11 & Drinking \\
\hline & \multirow[t]{3}{*}{ Olive baboon } & \multirow[t]{3}{*}{ Papio anubis } & Hind skin/skin & $\begin{array}{l}\text { Broken/misplaced bone } \\
\text { and wound/burning }\end{array}$ & 9 & 25 & Tying \\
\hline & & & Meat & $\begin{array}{l}\text { Rabies prevention for dogs } \\
\text { and HIV/AIDS }\end{array}$ & 13 & 36 & Eating \\
\hline & & & Bile, meat & AIDS & 6 & 17 & Eating, drinking \\
\hline & Cat & Felis domesticus & Skin & Spiritual problem & 3 & 8 & Tying \\
\hline & \multirow[t]{5}{*}{ Elephant } & \multirow[t]{5}{*}{ Elephas maximus } & Bile & Kidney failure & 3 & 8 & Drinking \\
\hline & & & Bone & Herpes and diarrhea & 6 & 17 & Massaging \\
\hline & & & Ivory & Herpes & 3 & 8 & Anointing \\
\hline & & & Urine & Herpes, urination disorder & 3 & 8 & Drinking \\
\hline & & & Skin & $\begin{array}{l}\text { Herpes, back pain, skin } \\
\text { wound, and trachoma }\end{array}$ & 6 & 17 & Anointing \\
\hline & Bear & Melursus ursinus & Bile & Epilepsy & 4 & 11 & Drinking \\
\hline & Vervet monkey & Chlorocebus pygerythrus & Meat & $\begin{array}{l}\text { For STDs, anemia for } \\
\text { children }\end{array}$ & 3 & 8 & Eating \\
\hline & \multirow[t]{2}{*}{ Common fox } & \multirow[t]{2}{*}{ Canis spp. } & $\begin{array}{l}\text { Brain tissue and } \\
\text { meat }\end{array}$ & Epilepsy, mental disorder & 4 & 11 & Eating/drinking \\
\hline & & & Bile & $\begin{array}{l}\text { Toothache, eye problem, } \\
\text { and internal problem }\end{array}$ & 2 & 5.6 & Drinking \\
\hline & Giraffe & Giraffa camelopardalis & Urine and milk & TB & 3 & 8 & Drinking \\
\hline & Dog & Canis familaries & Bone & Epilepsy & 3 & 8 & Tying \\
\hline & \multirow[t]{3}{*}{ Ethiopian hare } & \multirow[t]{3}{*}{ Lepus fagani } & Excreta & Soars/wound & 4 & 11 & Anointing \\
\hline & & & Meat & Cattle disorder, epilepsy & 8 & 22 & $\begin{array}{l}\text { Fumigation, } \\
\text { drinking }\end{array}$ \\
\hline & & & Fat & Wart & 5 & 14 & Anointing \\
\hline & Groundhog & Marmota monax & Meat & $\begin{array}{l}\text { For coughing and fattening } \\
\text { baby }\end{array}$ & 7 & 19 & Eating \\
\hline & Bat & Cynopterus sphinx & Meat & Hepatitis, mental disorder & 21 & 58 & Eating \\
\hline \multirow[t]{3}{*}{ Birds } & \multirow[t]{2}{*}{ Vulture } & \multirow[t]{2}{*}{ Gyps spp. } & Leg & Epilepsy & 3 & 8 & Fumigation \\
\hline & & & Meat & Mental disorder & 4 & 11 & Eating \\
\hline & Pigeon & Columba livia & Meat & $\begin{array}{l}\text { Mental disorder, body } \\
\text { fracture, and heart failure }\end{array}$ & 12 & 33 & Eating \\
\hline
\end{tabular}


Table 8 Medicinal animals, parts/products used, and their fidelity level (Continued)

\begin{tabular}{|c|c|c|c|c|c|c|c|}
\hline $\begin{array}{l}\text { Animal } \\
\text { group }\end{array}$ & $\begin{array}{l}\text { Common } \\
\text { name }\end{array}$ & Scientific name & $\begin{array}{l}\text { Parts/product } \\
\text { used }\end{array}$ & $\begin{array}{l}\text { Ailments } \\
\text { treated }\end{array}$ & $\begin{array}{l}\text { No. of } \\
\text { respondents } \\
\text { claimed }(n)\end{array}$ & $\begin{array}{l}\text { Fidelity } \\
\text { level (FL) }\end{array}$ & $\begin{array}{l}\text { Mode of } \\
\text { applications }\end{array}$ \\
\hline & Duck & Duck spp. & Meat & TB & 4 & 11 & Eating \\
\hline & Ostrich & Struthio camelus & Meat and egg & $\begin{array}{l}\text { Muscle strain and broken } \\
\text { bone and paralysis }\end{array}$ & 4 & 11 & $\begin{array}{l}\text { Massaging, } \\
\text { anointing }\end{array}$ \\
\hline & Hen & Gallus gallus domesticus & Whole body & $\begin{array}{l}\text { For physical injury and } \\
\text { wound }\end{array}$ & 9 & 25 & Drinking \\
\hline & & & Liver and fat & Swelling wound, pneumonia & 16 & 44 & Eating \\
\hline & Osprey & Pandion haliaetus & Bone & Epilepsy, body fracture & 5 & 14 & Tying \\
\hline & Erckel's francolin & Pternistis erckelii & Meat & Internal problem & 3 & 8 & Eating \\
\hline & & & Bile & STDS & 3 & 8 & Drinking \\
\hline & $\begin{array}{l}\text { Red billed } \\
\text { Oxpecker }\end{array}$ & $\begin{array}{l}\text { Buphagus } \\
\text { erythrorhynchus }\end{array}$ & Blood & Skin fungus & 4 & 11 & Anointing \\
\hline & Bald eagle & $\begin{array}{l}\text { Haliaeetus } \\
\text { leucocephalus }\end{array}$ & Blood & Skin fungus & 4 & 11 & Anointing \\
\hline \multirow[t]{14}{*}{ Reptiles } & Snake & Naja naja & Coat & Headache & 2 & 5.6 & Tying \\
\hline & & & Venom & Malaria and snake bite & 4 & 11 & Anointing \\
\hline & & & Head & $\begin{array}{l}\text { Diarrhea, evil eye, and } \\
\text { headache }\end{array}$ & 6 & 17 & Tying \\
\hline & Crocodile & Crocodylus spp. & Bile & $\begin{array}{l}\text { Coughing, TB, teeth } \\
\text { rheumatism }\end{array}$ & 4 & 11 & $\begin{array}{l}\text { Drinking } \\
\text { Anointing }\end{array}$ \\
\hline & & & Bone & Communicable disease & 3 & 8 & Tying \\
\hline & & & Teeth & Epilepsy & 2 & 5.6 & Tying \\
\hline & Python & Python spp. & Bone & Rabies and swelling & 3 & 8 & $\begin{array}{l}\text { Tying and } \\
\text { Banding }\end{array}$ \\
\hline & & & Tail and bone & Cancer and swelling & 3 & 8 & Banding \\
\hline & & & Fat & Wound and ear disease & 7 & 19 & Banding, \\
\hline & & & Meat & $\begin{array}{l}\text { Rabies, foot crack, and } \\
\text { ear disorder }\end{array}$ & 13 & 36 & $\begin{array}{l}\text { Eating, } \\
\text { anointing }\end{array}$ \\
\hline & Tortoise & Testudo graeca & Teeth & Swelling & 3 & 8 & Heating \\
\hline & & & Shell & $\begin{array}{l}\text { Trypanosomiasis, nose } \\
\text { bleeding }\end{array}$ & 6 & 17 & Fumigation \\
\hline & Chameleon & Chamaeleo chamaeleon & Whole body & Cancer, body fattening & 6 & 17 & Tying \\
\hline & Lizard & Lacertilia spp. & Whole body & Dry cough and anemia & 3 & 8 & Drinking \\
\hline \multirow[t]{2}{*}{ Fish } & Fish & Any fish spp. & Meat & Rheumatism & 4 & 11 & Eating \\
\hline & & & Bile & Eye disorder & 3 & 8 & Eating \\
\hline \multirow[t]{8}{*}{ Arthropods } & Scorpion & $\begin{array}{l}\text { Palamnaeus } \\
\text { swammerdami }\end{array}$ & Meat & Scorpion bite & 6 & 17 & Massaging \\
\hline & Bee & Apis mellifera & Honey & $\begin{array}{l}\text { Wart, asthma, diarrhea, } \\
\text { throat pain, stomachache, } \\
\text { cough, TB, mumps, heart } \\
\text { failure }\end{array}$ & 35 & 97 & Eating, drinking \\
\hline & & & Larvae & Stomach disorder & 3 & 8 & Drinking \\
\hline & Termite (Queen) & All spp. & Whole body & Fattening of livestock & 3 & 8 & Eating \\
\hline & Field cricket & Gryllus campestris & Whole body & Eye disease & 3 & 8 & Eating \\
\hline & Gnat (small insect) & All spp. & Honey & $\begin{array}{l}\text { Stomachache, eye disorder, } \\
\text { and coughing }\end{array}$ & 13 & 36 & Eating \\
\hline & Bumble bee & Bombus spp. & Honey & $\begin{array}{l}\text { Coughing, malaria, and } \\
\text { stomachache }\end{array}$ & 3 & 8 & Eating \\
\hline & Ticks & All tick spp. & Blood & Fungal disease on the skin & 3 & 8 & Anointing \\
\hline
\end{tabular}


Table 8 Medicinal animals, parts/products used, and their fidelity level (Continued)

\begin{tabular}{|c|c|c|c|c|c|c|c|}
\hline $\begin{array}{l}\text { Animal } \\
\text { group }\end{array}$ & $\begin{array}{l}\text { Common } \\
\text { name }\end{array}$ & Scientific name & $\begin{array}{l}\text { Parts/product } \\
\text { used }\end{array}$ & $\begin{array}{l}\text { Ailments } \\
\text { treated }\end{array}$ & $\begin{array}{l}\text { No. of } \\
\text { respondents } \\
\text { claimed }(n)\end{array}$ & $\begin{array}{l}\text { Fidelity } \\
\text { level (FL) }\end{array}$ & $\begin{array}{l}\text { Mode of } \\
\text { applications }\end{array}$ \\
\hline Annelid & Leeches & All spp. & Head & Rheumatism & 3 & 8 & Massaging \\
\hline
\end{tabular}

This study showed that traditional medicines were administrated by drinking, eating, anointing, tying, branding, fumigation, and massaging. The study conducted by Gidey Yirga et al. showed most of traditional medicines were administrated orally and through dermal. Fumigating materials such as smokes were also entering into the body using nasal opening to treat different ailments. Some parts of animals such as bones, skin, and teeth were believed to be medicine by tying on the neck or other parts of the body [27].

The majority of the remedy preparations did not have additive substance while the remaining had different additive substances like sugar, water, butter, honey, teff and millet flour salt, spice, milk, egg, and coffee. The result of this study is similar to research conducted by Gidey Yirga et al. [27]. Haileselasie stated that many animals were used for the treatment of multiple ailments singly or in combinations with other animal products or/and plants like seeds, flowers, latex (resins in some cases), and roots [22].

The honey of bee species (Apis mellifera) is known to relieve wart, asthma, diarrhea, throat pain, stomachache, cough, and tuberculosis and achieves the highest fidelity level, whereas biles of common fox (Canis spp.) to cure eye problem and toothache, upper coats of snake (Naja naja) to cure headache, and teeth of crocodile (Crocodylus spp.) to cure epilepsy have the lowest fidelity level. On the other hand, Jaroli et al. stated that the uses of animals that are commonly known by the Garasiya informants have higher fidelity levels than less common known species [27]. He reported the cooked flesh of bat (Cynopterus sphinx) used to relieved cough and fever has the highest FL followed by blood of pigeon (Columba livia) to treat paralysis and urine of cow (Bos taurus) for wound healing, while the flesh of the pig (Sus scrofa) to relieve muscular pain and elephant (Elephas maximus) for pimples have the lowest fidelity level.

The finding of this study suggested that the traditional zootherapeutic remedial measures followed by the native people of Metema Woreda plays an important role in their primary healthcare. The documentation of this indigenous knowledge on animal-based medicines should be very helpful in the formulations of strategies for sustainable management and conservation of bio-resource as well as providing potential for novel drug discoveries [21].

\section{Conclusions}

The result shows that animals and their parts/products occupy key positions in the traditional medicine and medical practices to treat different ailments. Whole bodies or parts/ products of traditional medicinal animals were used as a medicine. It was obvious that the members of the local communities studied possessed considerable knowledge related to preparation, administration, parts/products used, ingredients added, and other issues of traditional remedies. However, efforts to document, conserve, and manage the indigenous knowledge and skill were very scarce, and important indigenous knowledge is getting lost together with the elders and experts. Hence, it is important to document, conserve, and manage the indigenous knowledge, and further research should be done to test the products scientifically for product development.

\section{Acknowledgements}

We are very much grateful to all the respondents who shared their traditional zootherapeutic knowledge; without their contribution, this study would have been impossible. Furthermore, we would like to extend our gratitude to the College of Science, Bahir Dar University, which supplied laboratory room and required materials. We also thank Metema Woreda administrators and kebele leaders for their willingness to participate in the study. Finally, we would like to say thank you to both two reviewers for their insightful comments and suggestions for the improvements of this manuscript.

\section{Availability of data and materials}

The data used and analyzed during the current study is available from the corresponding author on a reasonable request, without disclosure of the interviewees.

\section{Declarations}

We confirm that this work is original and has not been published elsewhere, nor is it currently under consideration for publication elsewhere.

\section{Authors' contributions}

FA, SA, and MA proposed the research idea and collected the data from the respondents. FA organized the data in computer, did the analysis, interpretation, and identification, and wrote the manuscript. SA and MA revised the manuscript for scientific content and did the language check. All authors read and approved the final manuscript.

\section{Ethics approval and consent to participate}

The ethics approval is not applicable. Written consent by the authors was obtained before the interviews. We explained the objectives of the research to each respondent, when we also had a chance to answer questions and clear doubts. We assured them that their information was anonymous and that it was only for research purposes.

\section{Consent for publication}

This manuscript does not contain any individual person's data, and further consent for publication is not required.

\section{Competing interests}

The authors declare that they have no competing interests.

\section{Publisher's Note}

Springer Nature remains neutral with regard to jurisdictional claims in published maps and institutional affiliations. 
Received: 2 October 2017 Accepted: 3 May 2018

Published online: 23 May 2018

\section{References}

1. Lohani U, Rajbhandari K, Shakuntala K. Need for systematic ethnozological studies in the conservations of ancient knowledge systems of Nepal. Indian J Tradi Knowl. 2008;7(4):634-7.

2. Lev E. Traditional healing with animals (zootherapy); medieval to presentday Levantine practice. J Ethnopharmacol. 2003;86:107-18.

3. Alves RRN, Souto WMS. Ethnozoology: a brief introduction. Ethnobiol Conserv. 2015;4:1-13.

4. Costa-Neto EM. Animal-based medicines: biological prospection and the sustainable use of zootherapeutic resources. Ann Brazilian Acad Sci. 2005;77:33-43.

5. Anageletti LR, Agrimi U, Curia C, French D, Mariani-Costantini R. Healing rituals and sacred serpents. Lancet. 1992;340:223-5.

6. Rosner F. Pigeons as a remedy (segulah) for jaundice. N Y State J Med. 1992;92:189-92

7. Adeola MO. Importance of wild animals and their parts in the culture, religious festivals and traditional medicines of Nigeria. Environ Conserv. 1992:19:125-34.

8. Kang SP. Question of attitude: South Korea's traditional medicine practitioners and wildlife conservation. Hong Kong: TRAFFIC East Asia; 2003.

9. Anyinam C. Ecology and ethnomedicine: exploring links between current environmental crisis and indigenous medical practices. Soc Sci Med. 1995; 40:321-9.

10. Alves RRN, Rosa IL. Why study the use of animal products in traditional medicines? J Ethnobiol Ethnomed. 2005;10:1746-4269.

11. Meyer-Rochow VB. Therapeutic arthropods and other, largely terrestrial, folkmedicinally important invertebrates: a comparative survey and review. J Ethnobiol Ethnomed. 2017;13:9.

12. Whiting MJ, Williams VL and Hibbitts TJ. Animals traded for traditional medicine at the Faraday market in South Africa: species diversity and conservation implications. J zool. 2010;284:84-96.

13. CNCTHM (China National Corporation of Traditional and Herbal Medicine). In Materia medica commonly used in China. Beijing: Science Press; 1995.

14. Alves RR, Rosa IL. The use of animal-based remedies in urban areas of NE and N Brazil. J Ethnopharmacol. 2007;113:541-55.

15. Costa-Neto EM. Implications and applications of folk zootherapy in the state of Bahia, Northeastern Brazil. Sustain Dev. 2004;12(3):161-74.

16. Alves RR, Vieira WL, Santana GG. Reptiles used in traditional folk medicine: conservation implications. Biodivers Conserv. 2008;17(1):2037-49.

17. Alves RRN. Faun used in popular medicine in Northeast Brazil. J Ethnobiol Ethnomed. 2009:5:1-18.

18. Birhanu Z. Traditional use of medicinal plants by the ethnic groups of Gondar Zuria District, North-Western Ethiopia. J Nat Rem. 2013;13(1):2320-3358.

19. ILRI (International Livestock Research Institute). Initial draft report, Metema pilot learning site diagnosis and program design; 2005.

20. ARDO (Agricultural and Rural Development Office). The Woreda annual report: Shihedy; 2005.

21. Borah MP, Brasad SB. Ethnozoological study of animals based medicines used by traditional healers and indigenous inhabitants in the anointing area Gibbon Wildlife Sanctuary, Assam, India. J Ethnobiol Ethnomed. 2017;13:39.

22. Haileselasie T. Traditional zootherapeutic studies in Degu'a Tembien, Northern Ethiopia. Curr Res J Biol Sci. 2012;4(5):563-9.

23. Alexiades MN. Collecting ethnobotanical data. In: Alexiades MN, Sheldon JW, editors. Selected guideline for ethnobotanical research a field manual. New York: Bronex; 1996. p. 40-102.

24. Yirga G, Teferi M, Gebreslassea Y. Ethnozoological study of traditional medicinal animals used by the people of Kafta-Humera District, Northern Ethiopia. Int J Med Med Sci. 2011;3(10):316-20.

25. Oliveira ES, Torres DF, Brooks SE, Alves RRN. The medicinal animal markets in the metropolitan region of Natal City, Northeastern Brazil. J Ethnopharmacol. 2010;130:54-60.

26. Chakravorty J, Meyer-Rochow VB, Ghosh S. Vertebrates used for medicinal purpose by members of Nyishi and Galo tribes in Arunachal Pradesh (North-East India). J Ethnobiol Ethnomed. 2011;7:13.

27. Jaroli DP, Mahawar MM, Vyas N. An ethnozoological study in the adjoining areas of Mount Abu wildlife sanctuary, India. J Ethnobiol Ethnomed. 2010;6:6.

\section{Ready to submit your research? Choose BMC and benefit from:}

- fast, convenient online submission

- thorough peer review by experienced researchers in your field

- rapid publication on acceptance

- support for research data, including large and complex data types

- gold Open Access which fosters wider collaboration and increased citations

- maximum visibility for your research: over $100 \mathrm{M}$ website views per year

At BMC, research is always in progress.

Learn more biomedcentral.com/submissions 